\title{
Tuning Bismuth Activator Valence in Calcium Halophosphate Solid Solution by Controlling Activator Site
}

\author{
ZHANG Qing-Fu ${ }^{1}$, LI Chen ${ }^{1}$, SONG Zhi-Guo ${ }^{1}$, LI Yong-Jin ${ }^{2}$, QIU Jian-Bei ${ }^{1}$, YANG Zheng-Wen ${ }^{1}$ \\ (1. School of Materials Science and Engineering, Kunming University of Science and Technology, Kunming 650093, China; \\ 2. Department of Science Research, Yunnan Technology and Business University, Kunming 651700, China)
}

\begin{abstract}
Effect of halide ions on valence state and luminescence property of Bi ions in calcium halophosphates was investigated. Bi-activated fluorapatite-chlorapatite solid solutions were synthesized by a solid state reaction. The content ratio between $\mathrm{Bi}^{2+}$ and $\mathrm{Bi}^{3+}$ ions in the crystals could be tuned rationally by the component ratio of $\mathrm{F}^{-} / \mathrm{Cl}^{-}$, and the absent emission of $\mathrm{Bi}^{2+}$ ion occur when halide ions are all occupied by $\mathrm{Cl}^{-}$ions. The origin of this change is because the $\mathrm{Ca}_{2}$ site of calcium halophosphate is split into $\mathrm{Ca}(2) \mathrm{a}$ and $\mathrm{Ca}(2) \mathrm{b}$ sites for $\mathrm{F}^{-}$and $\mathrm{Cl}^{-}$as the nearest neighbors, and the $\mathrm{Ca}(2) \mathrm{a}$ is adopted to offer activator site that enables $\mathrm{Bi}^{3+}$ to be self-reduced. The results in this study can provide a scientific reference for controlling the valence state of $\mathrm{Bi}$ ions in crystals.
\end{abstract}

Key words: calcium halophosphate; bismuth; luminescence properties; control

Recently, besides the excellent potential applications in NIR optical sources ${ }^{[1-9]}$, bismuth also has received increasing attention due to as an important luminescence active center used in displaying and lighting fields ${ }^{[7-11]}$, especially divalent $\mathrm{Bi}$. Because of the particular electronic band structure, it has been considered recently to have the application in alternative red or orange emitting phosphors that can be excited by blue or UV light emitting diodes $(\mathrm{LEDs})^{[2]}$. However, in stark contrast to the rare-earth and transition-metal ions with relatively simple ionic state, $\mathrm{Bi}$ has been identified to be present in various forms, including $\mathrm{Bi}^{3+}, \mathrm{Bi}^{2+}, \mathrm{Bi}^{+}, \mathrm{Bi}$ atom, $\mathrm{Bi}$ cluster and Bi nanocrys$\operatorname{tal}^{[12-20]}$. One important reason is that the activation energy of the chemical transformations of these species is relatively low ${ }^{[6,12]}$. This means both the reducibility of prepared atmosphere and the local chemical condition of crystal structure are anticipated to be sufficient enough to trigger the valence transformation of $\mathrm{Bi}$ ion. As a result, stabilizing the divalent bismuth ion in phosphors faces difficulties, and only a handful of matrix materials are known up to now in which efficient stabilization of the $\mathrm{Bi}^{2+}$ ion is possible ${ }^{[15,21-23]}$.

Very recently, we reported the orange emission and violet emission of $\mathrm{Bi}$ ion in $\mathrm{Ca}_{5}\left(\mathrm{PO}_{4}\right)_{3} \mathrm{~F}$ and $\mathrm{Ca}_{5}\left(\mathrm{PO}_{4}\right)_{3} \mathrm{Cl}$ prepared in air, and the latter one was considered to be ascribed to $\mathrm{Bi}^{2+}$ ion typical emission ${ }^{[5,24-25]}$. It offers the possibility that $\mathrm{Bi}^{2+}$ ion may be controlled by the content of halogen in the apatite crystals. In the present work, we carefully investigated the effect of halide ions on valence state change and luminescence property of $\mathrm{Bi}$ ions in calcium halophosphates. The content ratio between $\mathrm{Bi}^{2+}$ and $\mathrm{Bi}^{3+}$ ions in the crystals could be tuned rationally by the source ratio of $\mathrm{F}^{-} / \mathrm{Cl}^{-}$, and the absent emission of $\mathrm{Bi}^{2+}$ ion will occur when the halide ions are all occupied by $\mathrm{Cl}^{-}$ions. The reason for this change was discussed according to the fine structure variation of haloapatite solid solutions, which may help to design the composition of $\mathrm{Bi}^{2+}$-activated phosphors and provide a scientific reference for the control of $\mathrm{Bi}$ ions valence state in crystals.

\section{Experimental details}

\subsection{Preparations}

The bismuth doped $\mathrm{Ca}_{4.99} \mathrm{Bi}_{0.01}\left(\mathrm{PO}_{4}\right)_{3} \mathrm{~F}_{(1-x)} \mathrm{Cl}_{x}(x=0,0.4$, $0.5,0.6,0.7,0.8$ and 1) samples were synthesized via solid state reaction method in air atmosphere. For that, analytical grade reagents $\mathrm{CaCO}_{3}(99.99 \%),\left(\mathrm{NH}_{4}\right)_{2} \mathrm{HPO}_{4}(99 \%), \mathrm{NH}_{4} \mathrm{~F}$ (99\%), $\mathrm{NH}_{4} \mathrm{Cl}(99 \%)$ and $\mathrm{Bi}_{2} \mathrm{O}_{3}(99.99 \%)$ were used as raw materials. Individual batches of $5 \mathrm{mmol}$ were weighed according to stoichiometric compositions and mixed thoroughly. Both $\mathrm{NH}_{4} \mathrm{~F}$ and $\mathrm{NH}_{4} \mathrm{Cl}$ were added in excess of $10 \mathrm{~mol} \%$ to compensate for volatilization losses. The grinded powder mixtures were then transferred into crucibles for a two-step heating. First, the mixed raw materials 
were preheated at $400^{\circ} \mathrm{C}$ for $4 \mathrm{~h}$ and grounded together for second time. Subsequently, all products were sintered at elevated temperature about $1100^{\circ} \mathrm{C}$ for $2 \mathrm{~h}$ again in the air. Then, the resulting samples were obtained.

\subsection{Characterization}

Crystal structures of the obtained samples were analyzed by X-ray powder diffraction (XRD) with a Rigaku D/max 2200 Diffractometer with $\mathrm{Cu} \mathrm{K} \alpha(\lambda=0.1542 \mathrm{~nm})$ radiation at $36 \mathrm{kV}$ and $30 \mathrm{~mA}$. The emission and excitation spectra were obtained with a HITACHI F-7000 fluorescence spectrophotometer, using a static Xe lamp $(150 \mathrm{~W})$. All the measurements were carried out at room temperature.

\section{Results and discussion}

\subsection{Crystal structure}

The crystallography of $\mathrm{Ca}_{5}\left(\mathrm{PO}_{4}\right)_{3} \mathrm{M}(\mathrm{M}=\mathrm{F}$ and $\mathrm{Cl})$ is well documented in the previous work ${ }^{[5]}$. In $\mathrm{Ca}_{5}\left(\mathrm{PO}_{4}\right)_{3} \mathrm{M}$ lattice, the position of $\mathrm{M}^{-}$ion is responsible for the difference in the symmetry, there are two asymmetrical cationic $\left(\mathrm{Ca}^{2+}\right)$ sites in this system with the first site $\mathrm{Ca}^{2+}(1)$ at the center of a slightly distorted tricapped trigonal prism constituted by six oxygen atoms of the $\mathrm{PO}_{4}$ network corresponding to $\mathrm{C}_{3}$ point group symmetry. And the second type of site $\mathrm{Ca}^{2+}(2)$ is coordinated with six oxygen atoms plus two $\mathrm{M}^{-}$ions, with the local symmetry around the $\mathrm{Ca}^{2+}(2)$ site described by $\mathrm{C}_{\mathrm{s}}$ point group. These two cationic sites and crystal structure can be pictorially represented as Fig. 1.

The XRD patterns of $\mathrm{Bi}$ doped $\mathrm{Ca}_{5}\left(\mathrm{PO}_{4}\right)_{3} \mathrm{~F}_{(1-x)} \mathrm{Cl}_{x}$ samples are given in Fig. 2(a). It shows that the diffraction peaks of the samples with pure $\mathrm{F}$ or $\mathrm{Cl}$ can be indexed as a pure phase, which coincide well with the reference data of $\mathrm{Ca}_{5}\left(\mathrm{PO}_{4}\right)_{3} \mathrm{~F}$ (PDF 15-0876) and $\mathrm{Ca}_{5}\left(\mathrm{PO}_{4}\right)_{3} \mathrm{Cl}$ (PDF 33-0271), respectively ${ }^{[26]}$. On the other hand, the representative a-lattice lattice parameter of the prepared samples varies nearly linearly with the change of $\mathrm{F} / \mathrm{Cl}$ ratio, indicating that apatite solid solutions are formed (Fig. 2(b) $)^{[26]}$.

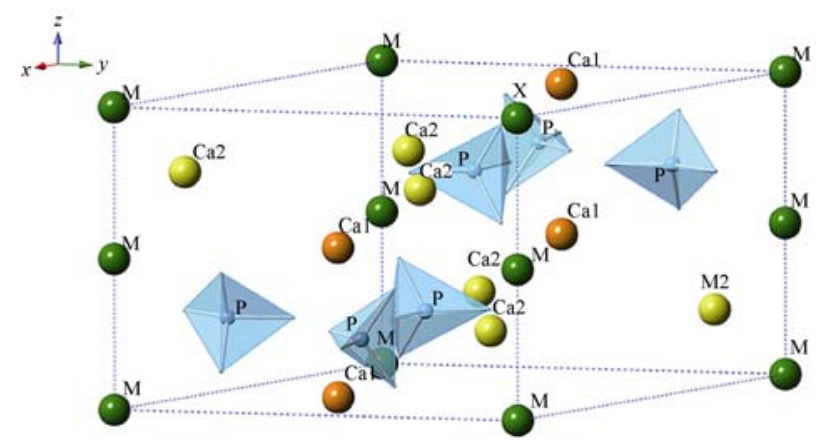

Fig. 1 Two cationic sites and crystal structure of $\mathrm{Ca}_{5}\left(\mathrm{PO}_{4}\right)_{3} \mathrm{M}$
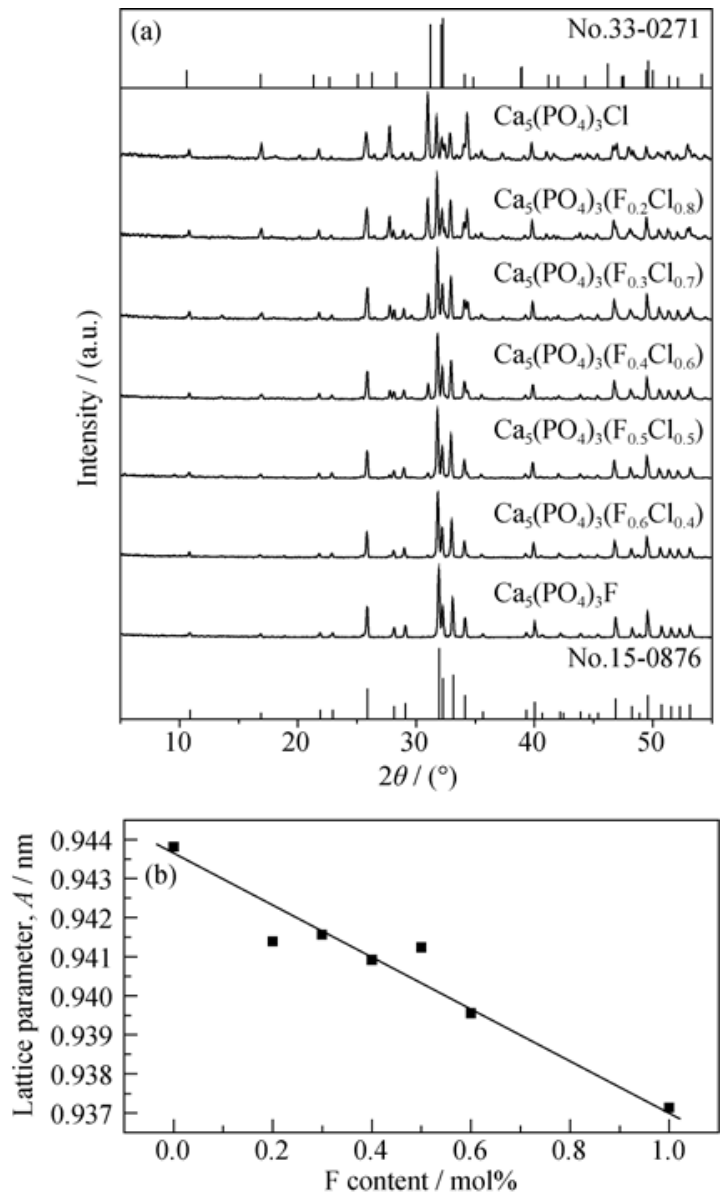

Fig. 2 (a) XRD patterns and (b) A-lattice lattice parameter of the prepared samples varies linearly with the change of $\mathrm{F}$ content

It should be clarified that the content ratio between raw material of $\mathrm{F}$ and $\mathrm{Cl}$ source possibly cannot present the actual ratio of $\mathrm{F} / \mathrm{Cl}$ in resulted crystals, due to the different reaction and volatilization rate. But the method presented in this study can indicate the variation of ratio of $\mathrm{F} / \mathrm{Cl}$ in the samples directly.

\subsection{Luminescence properties}

Before investigating the emission change of $\mathrm{Bi}$ doped calcium halophosphate solid solutions, the luminescence properties of $\mathrm{Bi}$ doped $\mathrm{Ca}_{5}\left(\mathrm{PO}_{4}\right)_{3} \mathrm{Cl}$ and $\mathrm{Ca}_{5}\left(\mathrm{PO}_{4}\right)_{3} \mathrm{~F}$ should be clarified respectively, which have been investigated in our previous research ${ }^{[5,7,27]}$. Fig. 3(a) and (b) show the excitation and emission spectra of $\mathrm{Ca}_{4.99}\left(\mathrm{PO}_{4}\right)_{3} \mathrm{Cl}$ and $\mathrm{Ca}_{4.99}\left(\mathrm{PO}_{4}\right)_{3} \mathrm{~F}$ doped with $1 \% \mathrm{Bi}$. For sample of $\mathrm{Ca}_{5}\left(\mathrm{PO}_{4}\right)_{3} \mathrm{Cl}: 1 \% \mathrm{Bi}$, it exhibits an asymmetric emission band peaked at $397 \mathrm{~nm}$ under UV light excitation, which can be attributed to the fact that $\mathrm{Bi}^{3+}$ will replace $\mathrm{Ca}^{2+}$ on two different cation sites in $\mathrm{Ca}_{5}\left(\mathrm{PO}_{4}\right)_{3} \mathrm{Cl}$ lattice. However, for sample of $\mathrm{Ca}_{5}\left(\mathrm{PO}_{4}\right)_{3} \mathrm{~F}$ : $\mathrm{Bi}$, two excitation bands in the excitation spectra monitored at $397 \mathrm{~nm}$ are observed, one dominating at $354 \mathrm{~nm}$ and another weak shoulder centering at $284 \mathrm{~nm}$. Moreover, an ultra-broadband emission in the longer wavelength order could also be seen 

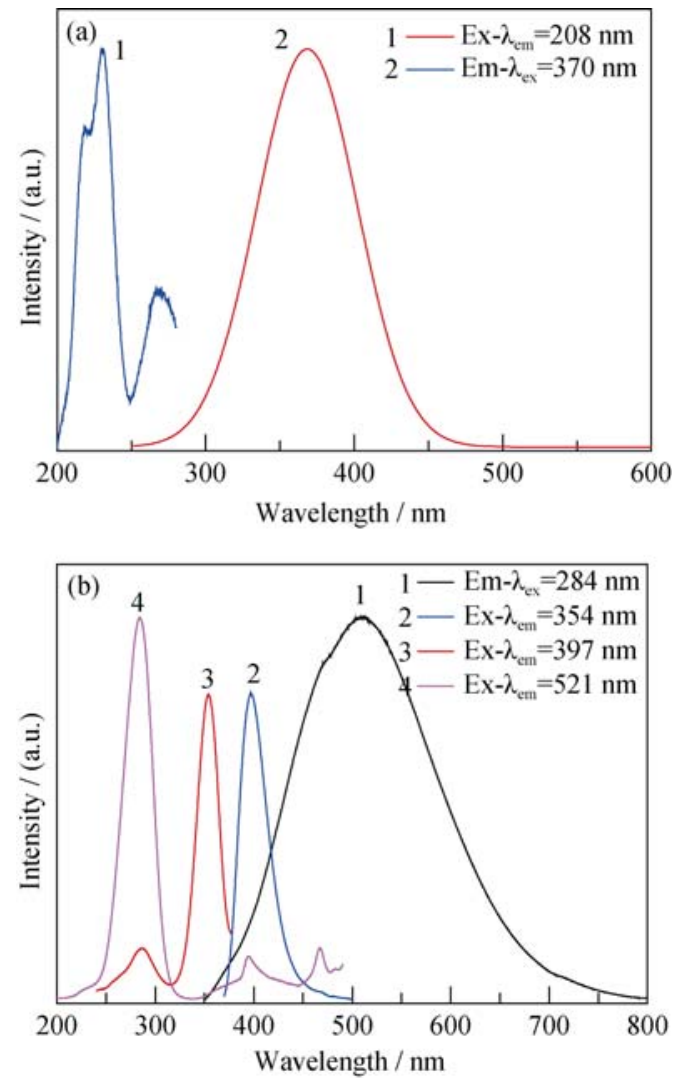

Fig. 3 Excitation and emission spectra of (a) $\mathrm{Ca}_{4.99}\left(\mathrm{PO}_{4}\right)_{3} \mathrm{Cl}$ and (b) $\mathrm{Ca}_{4.99}\left(\mathrm{PO}_{4}\right)_{3} \mathrm{~F}$ doped with $1 \% \mathrm{Bi}$

When excited by $284 \mathrm{~nm}$, which peaks at $521 \mathrm{~nm}$ and covers nearly whole visible spectrum to form the orange light emission. According to the traditional charge compensation principle as well as the mechanism for realizing the abnormal reduction of trivalent rare earth $\left(\mathrm{Re}^{3+}\right)$ ions in solid state compounds ${ }^{[28-31]}$, we supposed that the $\mathrm{Bi}^{3+}$ ions occupied $\mathrm{Ca}(1)$ sites could be reduced to $\mathrm{Bi}^{2+}$ ions in air, but not for that in $\mathrm{Ca}(2) \operatorname{sites}^{[5,30]}$. However, this cannot well explain the great difference of bismuth activator valence in the two apatite hosts with nearly identical structure.

To better understand the origin of this difference, we investigated the $\mathrm{Bi}$ emission dependence on the variation of $\mathrm{F}^{-} / \mathrm{Cl}^{-}$ratio. Fig. 4 shows that with the $\mathrm{F}^{-}$content decreasing, the emission performance related to $\mathrm{Bi}^{3+}$ increases, while that for $\mathrm{Bi}^{2+}$ ions reduces gradually. This means that the content ratio between $\mathrm{Bi}^{2+}$ and $\mathrm{Bi}^{3+}$ ions in the crystals could be tuned rationally by the content ratio of $\mathrm{F}^{-} / \mathrm{Cl}^{-}$, and the absent emission of $\mathrm{Bi}^{2+}$ ion will occur when the halide ions are all occupied by $\mathrm{Cl}^{-}$ion. Moreover, this interesting result offers a facile method to obtain the adjustable color of emission from blue to orange in a singlephased haloapatites activated by $\mathrm{Bi}$ ions.

\subsection{Solid solutions}

Generally, due to polarization and electronegativity difference between $\mathrm{F}^{-}$and $\mathrm{Cl}^{-}$ions ${ }^{[32-33]}$, the increasing
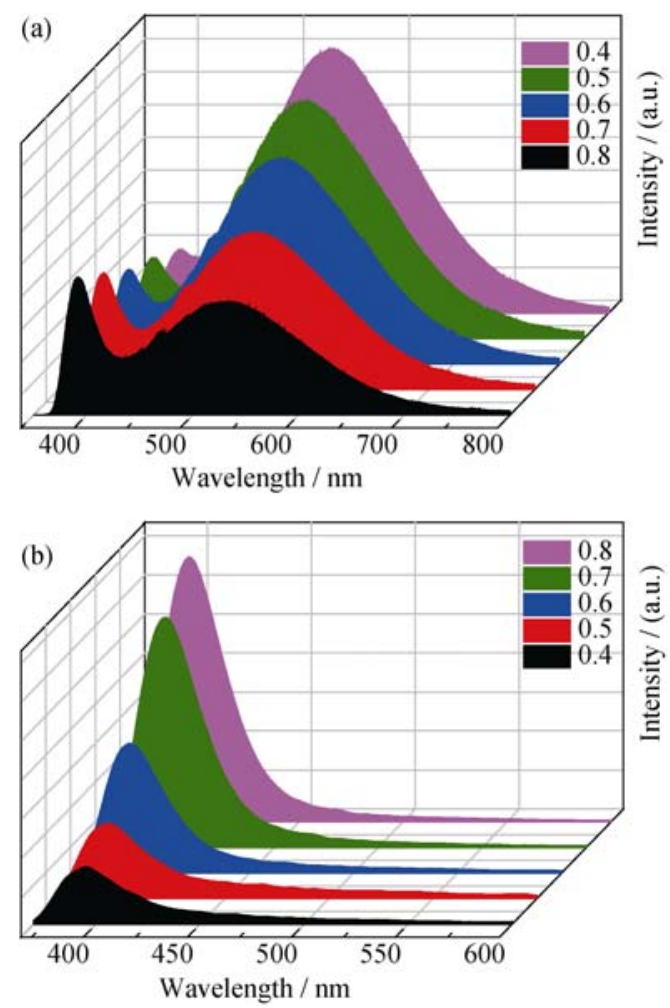

Fig. 4 The emission of (a) $\mathrm{Bi}^{2+}$ and (b) $\mathrm{Bi}^{3+}$-doped $\mathrm{Ca}_{4.99} \mathrm{Bi}_{0.01}\left(\mathrm{PO}_{4}\right)_{3} \mathrm{~F}_{(1-x)} \mathrm{Cl}_{x}(x=0.4,0.5,0.6,0.7$ and 0.8)

content of $\mathrm{F}^{-}$may have influence on reduction of doped aviators. For example, it has been reported that $\mathrm{Eu}^{3+}$ can be easily reduced to $\mathrm{Eu}^{2+}$ in fluorite glass ${ }^{[28,34-35]}$. However, in the haloapatite crystals, we considered that the content of $\mathrm{F}^{-}$, namely the reduction ability difference between $\mathrm{F}^{-}$ and $\mathrm{Cl}^{-}$ions should not be the direct reason for reducing $\mathrm{Bi}^{2+}$ ions. Because in previous work, we observed that the $\mathrm{Bi}^{3+}$ ions doped in the $\mathrm{Ca}_{5}\left(\mathrm{PO}_{4}\right)_{3} \mathrm{Cl}$ crystals could not be reduced in reduction air at high temperature ${ }^{[5]}$. Therefore, we proposed that the fine structure difference for the two kinds of apatite may be responsible for the valence tuning of $\mathrm{Bi}$ ions.

Previously, it has been found that the lattice parameters of the apatite solid solutions vary systematically with halogen composition ${ }^{[26]}$. As shown in Fig. 5(a), $\mathrm{F}^{-}$at the unit-cell position of $(0,0,1 / 4)$ is coordinated in a triangular-planar fashion by $\mathrm{Ca}$ at $(x, y, 1 / 4)$ on the $\mathrm{Ca}(2)$ site. In contrast to $\mathrm{F}^{-}$, which occupies a special position at $(0,0$, $1 / 4)$ in the unit cell, $\mathrm{Cl}^{-}$occupies split positions ranging from $0.346(4)$ to $0.4428(2)$ in the z-coordinate because of the larger ionic radius of $\mathrm{Cl}^{-}$(Fig. 5(b)). Moreover, as shown in Fig. 5(c), it has been confirmed that the $\mathrm{Ca}(2)$ site is also split into $\mathrm{Ca}(2) \mathrm{a}$ and $\mathrm{Ca}(2) \mathrm{b}$ sites for $\mathrm{F}^{-}$and $\mathrm{Cl}^{-}$ as nearest neighbors, respectively. In comparison to the $\mathrm{Ca}(2) \mathrm{a}-\mathrm{F}^{-}$arrangements, the larger $\mathrm{Cl}^{-}$ion presses the triangular arrangement of $\mathrm{Ca}$-ions outward to facilitate an energetic more favorable constellation resulting in the formation of $\mathrm{Ca}(2) \mathrm{b}-\mathrm{Cl}^{-}$arrangements, which leads to 


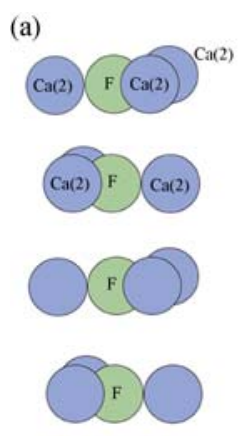

(b)

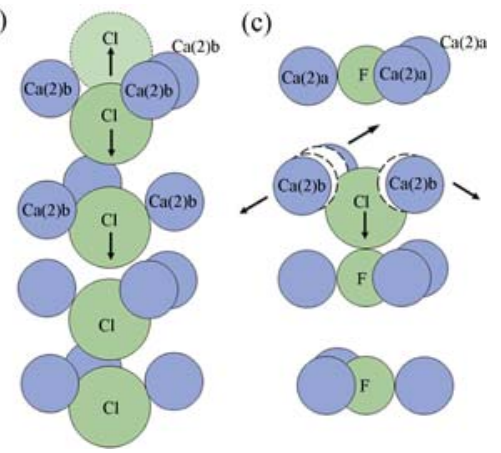

Fig. 5 Triangular-planar arrangement of $\mathrm{Ca}_{3} \mathrm{M}$ in haloapatite along the $z$-axis of (a) flourapatite, (b) chlorapatite, and (c) haloapatite solid solution. Substitution of $\mathrm{Cl}^{-}$for $\mathrm{F}^{-}$into the triangular arrangement and splitting of the $\mathrm{Ca}(2)$ site into $\mathrm{Ca}(2) \mathrm{a}$ and $\mathrm{Ca}(2) \mathrm{b}$

symmetry reduction. Importantly, the occupancies of the $\mathrm{Ca}(2) \mathrm{a}$ and $\mathrm{Ca}(2) \mathrm{b}$ sites have been confirmed to correlate strictly with the $\mathrm{F}-\mathrm{Cl}$ content ${ }^{[26]}$. This means the dependence of relative luminescence intensity of $\mathrm{Bi}^{2+} / \mathrm{Bi}^{3+}$ on the halogen composition is highly consistent with the ratio of $\mathrm{Ca}(2) \mathrm{a} / \mathrm{Ca}(2) \mathrm{b}$ sites. Herein, according to comprehensive survey of the performances of $\mathrm{Bi}$ doped calcium halophosphate solid solutions, an attempt was made to relate $\mathrm{Bi}^{2+}$ with its incorporation into the $\mathrm{Ca}(2) \mathrm{a}$ sits, which causes the activation of self-reduction for $\mathrm{Bi}^{3+}$ ions.

In order to confirm above assumption, we compared the emission peak position of $\mathrm{Bi}^{2+}$ ions in different samples, which have just one kind of sites in the apatite host. It is because the transition of $\mathrm{Bi}^{2+}$ is the $6 s \rightarrow 6 \mathrm{p}$ internal electronic configuration transition, which is very sensitive to its local structure ${ }^{[36-39]}$. This means if the self-reduction behavior of $\mathrm{B}^{3+}$ to $\mathrm{Bi}^{2+}$ is mainly related to the reduction effect of $\mathrm{F}^{-}$content rather than the occupancies of $\mathrm{Ca}(2) \mathrm{a}$ sites, its emission center position will change significantly with composition variation, just as observed in other hosts ${ }^{[14-15,39]}$. Conversely, when the self-reduction of $\mathrm{Bi}^{2+}$ centers just occurs at $\mathrm{Ca}(2)$ a sites, it means the nearest local environments of $\mathrm{Bi}^{2+}$ ions are nearly analogous and it will give an almost identical emission. Interestingly, as showed in Fig. 6, the center position of the orange broadband emission keeps nearly unchangeable when the content ration of $\mathrm{F} / \mathrm{Cl}$ varies. This could offer direct evidence for confirming the formation of $\mathrm{Bi}^{2+}$ at $\mathrm{Ca}(2)$ a sites of $\mathrm{Ca}_{5}\left(\mathrm{PO}_{4}\right)_{3} \mathrm{~F}_{(1-x)} \mathrm{Cl}_{x}$ solid solutions. It means that in calcium halophosphate solid solutions, the site and valence of $\mathrm{Bi}$ activator can be controlled and tuned facilely by the ration of $\mathrm{F} / \mathrm{Cl}$.

It should be noted that on the basis of the above conclusion, the $\mathrm{Bi}^{3+}$ ions that occupied $\mathrm{Ca}(2)$ sites could be reduced to $\mathrm{Bi}^{2+}$ ions in air, but not for that in $\mathrm{Ca}(1)$ sites as we proposed previously. In other word, that self-reduction behavior of $\mathrm{Bi}$ ion in the haloapatite crystals is partially

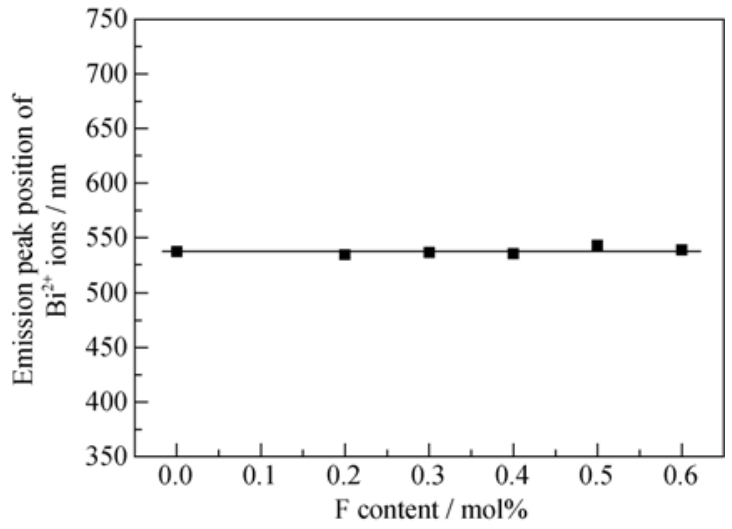

Fig. 6 The emission peak position of $\mathrm{Bi}^{2+}$ ions in samples with different $\mathrm{F}$ contents

different to the well-adopted conditions for realizing the abnormal reduction of $\mathrm{Re}^{3+[28-31,34]}$, which might enrich understanding mechanism of structure self-reduction and provide a scientific reference for the control of valence state of Bi ion in crystals. We think it might be related to the relatively lower activation energy of the chemical transformations of $\mathrm{Bi}$ ions. But the detailed mechanism for the surroundings of $\mathrm{Ca}^{2+}(2)$ a site that is beneficial for the formation and stabilization of $\mathrm{Bi}^{2+}$ have not been understood well, and further investigations will be done.

\section{Conclusion}

Bi doped $\mathrm{Ca}_{5}\left(\mathrm{PO}_{4}\right)_{3} \mathrm{~F}_{(1-x)} \mathrm{Cl}_{x}$ phosphors were prepared by solid state reaction method in air. The content ratio between $\mathrm{Bi}^{2+}$ and $\mathrm{Bi}^{3+}$ ions in the crystals could be tuned rationally by the content ratio of $\mathrm{F}^{-} / \mathrm{Cl}^{-}$, and the absent emission of $\mathrm{Bi}^{2+}$ ion will occur when the halide ions are all occupied by $\mathrm{Cl}^{-}$ion. The reason for this change can be described to the splitting $\mathrm{Ca}_{2}$ site of calcium halophosphate into $\mathrm{Ca} 2 \mathrm{a}$ and $\mathrm{Ca} 2 \mathrm{~b}$ sites for $\mathrm{F}^{-}$and $\mathrm{Cl}^{-}$as nearest neighbors, the latter of which is be beneficial for the stabilization of $\mathrm{Bi}^{2+}$ ions. The results in this study can help to the design of the composition of $\mathrm{Bi}^{2+}$-activated phosphor and provide a scientific reference for the control of valence state of $\mathrm{Bi}$ ion in crystals.

\section{References:}

[1] XU BEI-BEI, CHEN PING, ZHOU SHI-FENG, et al. Enhanced broadband near-infrared luminescence in Bi-doped glasses by co-doping with Ag. J. Appl. Phys., 2013, 113(18): 183506.

[2] PENG MINGYING, LOTHAR W. $\mathrm{Bi}^{2+}$-doped strontium borates for white-light-emitting diodes. Opt. Lett., 2009, 34(19): $2885-2887$.

[3] FRANK K, DIRK R, AND ALAN F. Mid-Infrared Laser Applica- 
tions in Spectroscopy. Springer Berlin Heidelberg, 2003: 458-529.

[4] FUJIMOTO Y, NAKATSUKA M. Optical amplification in bismuth-doped silica glass. Appl. Phys. Lett., 2003, 82(19): 3325-3326.

[5] LI CHEN, LI YONG-JIN, SONG ZHI-GUO, et al. Study on the effect of apatite structure on spectroscopic properties of bismuth activated alkaline earth metal chlorophosphate $\left[\mathrm{M}_{5}\left(\mathrm{PO}_{4}\right)_{3} \mathrm{Cl} ; \mathrm{M}=\right.$ Ca, Sr and Ba]. Mater. Chem. Phys., 2013, 139(1): 220-224.

[6] WAN RONG-HUA, SONG ZHI-GUO, LI YONG-JIN, et al. Investigation on the near-infrared-emitting thermal stability of Bi activated alkalineearth aluminoborosilicate glasses. J. Appl. Phys., 2015, 117(5): 053107.

[7] LI CHEN, SONG ZHI-GUO, QIU JIAN-BEI, et al. Broadband yel low-white and near infrared luminescence from Bi-doped $\mathrm{Ba}_{10}\left(\mathrm{PO}_{4}\right)_{6} \mathrm{Cl}_{2}$ prepared inreductiveatmosphere. J. Lumin., 2012, 132(7): 1807-1811.

[8] SUN HONG-TAO, AKINOBU H, FUMIAKI S, et al. Strong ultra-broadband near-infrared photoluminescence from bismuthembedded zeolites and their derivatives. Adv. Mater, 2009, 21(36): 3694-3698.

[9] SUN HONG-TAO, ZHOU JIA-JIA, QIU JIAN-RONG. Recent advances in bismuth activated photonic materials. Prog. Mater Sci., 2014, 64: 1-72.

[10] PENG MING-YING, DONG GUOPING, WONDRACZEK L, et al. Discussion on the origin of NIR emission from Bi-doped materials. J. Non-Cryst. Solids., 2011, 357(11): 2241-2245.

[11] WAN RONG-HUA, SONG ZHI-GUO, LI YONG-JIN, et al. Influence of alkali metal ions on thermal stability of Bi-activated NIR-emitting alkali-aluminoborosilicate glasses. Chinese Optics Letters, 2014, 12(11): 111601.

[12] PENG MING-YING, ZOLLFRANK C, WONDRACZEK L. Origin of broad NIR photoluminescence in bismuthate glass and Bi-doped glasses at room temperature. J. Phys.: Condens. Matter, 2009, 21(28): 285106.

[13] NIKL M, NOVOSElOV A, MIHOKOVA E, et al. Photoluminescence of $\mathrm{Bi}^{3+}$ in $\mathrm{Y}_{3} \mathrm{Ga}_{5} \mathrm{O}_{12}$ single-crystal host. J. Phys.: Condens. Matter, 2005, 17(21): 3367.

[14] SUN HONG-TAO, SHIMAOKA F, QIU JIANRONG, et al. Sensitized superbroadband near-IR emission in bismuth glass/Si nanocrystal superlattices. Opt. Lett., 2010, 35(13): 2215-2227.

[15] PENG MING-YING, DA NING, KROLIKOWSKI S, et al. Luminescence from $\mathrm{Bi}^{2+}$-activated alkali earth borophosphates for white LEDs. Opt. Express, 2009, 17(23): 21169-21178.

[16] PENG MING-YING, QIU JIAN-RONG, CHEN DAN-PING, et al. Superbroadband $1310 \mathrm{~nm}$ emission from bismuth and tantalum codoped germanium oxide glasses. Opt. Lett., 2005, 30(18):
2433-2435.

[17] SUN HONG-TAO, MATSUSHITA Y, SAKKA Y, et al. Synchrotron X-ray, photoluminescence, and quantum chemistry studies of bismuth-embedded dehydrated zeolite Y. J. Am. Chem. Soc., 2012, 134(6): 2918-2921.

[18] LIU BO-MEI, ZHANG ZHI-GANG, SUN HONG-TAO, et al. Unconventional luminescent centers in metastable phases created by topochemical reduction reactions. Angew. Chem. Int. Ed., 2016, 55(16): 4967-4971.

[19] SUN HONG-TAO, SAKKA Y, GAO HONG, et al. Ultrabroad near-infrared photoluminescence from $\mathrm{Bi}_{5}\left(\mathrm{AlCl}_{4}\right)_{3}$ crystal. J. Mater. Chem., 2011, 21(12): 4060-4063.

[20] SUN HONG-TAO, SAKKA Y, SHIRAHATA N, et al. Experimental and theoretical studies of photoluminescence from $\mathrm{Bi}_{8}{ }^{2+}$ and $\mathrm{Bi}_{5}{ }^{3+}$ stabilized by $\left[\mathrm{AlCl}_{4}\right]^{-}$in molecular crystals. J. Mater. Chem., 2012, 22(25): 12837-12841.

[21] PENG MING-YING, WONDRACZEK L. Orange-to-red emission from $\mathrm{bi}^{2+}$ and alkaline earth codoped strontium borate phosphors for white light emitting diodes. J. Am. Ceram. Soc., 2010, 93(5): $1437-1442$.

[22] HAMSTRA M A, FOLKERTS H F, BLASSE G. Red bismuth emission in alkaline-earth-metal sulfates. J. Mater. Chem., 1994, 4(8): 1349-1350.

[23] ZHOU YANG, YONG ZI-JUN, SUN HONG-TAO, et al. Ultrabroad photoluminescence and electroluminescence at new wavelengths from doped organometal halide perovskites. J. Phys. Chem. Lett., 2016, 7(14): 2735-2741.

[24] BLASSE G. Classical phosphors: a Pandora's box. J. Lumin., 1997, 72: 129-134.

[25] ARIMILLI S, NAG B, SRIVASTAVA A M. Luminescence of divalent bismuth in $\mathrm{M}^{2+} \mathrm{BPO}_{5}\left(\mathrm{M}^{2+}=\mathrm{Ba}^{2+}, \mathrm{Sr}^{2+}\right.$ and $\left.\mathrm{Ca}^{2+}\right)$-Condens. Matter. J. Lumin., 1998, 78(4): 239-243.

[26] SCHETTLER G, GOTTSCHALK M, HARLOV D E. A new semi-micro wet chemical method for apatite analysis and its application to the crystal chemistry of fluorapatite-chlorapatite solid solutions. Am. Mineral., 2011, 96(1): 138-152.

[27] LI CHEN, SONG ZHI-GUO, QIU JIAN-BEI, et al. Broadband orange emission from Bi activated calcium fluorophosphate. Mater. Res. Bull., 2014, 50: 490-493.

[28] HONG B C, KAWANO K. Syntheses of $\mathrm{CaF}_{2}$ : Eu nanoparticles and the modified reducing TCRA treatment to divalent Eu ion. Opt. Mater., 2008, 30(6): 952-956

[29] PENG MING-YING, PEI ZHI-WU, HONG GUANG-YAN, et al. Study on the reduction of $\mathrm{Eu}^{3+} \rightarrow \mathrm{Eu}^{2+}$ in $\mathrm{Sr}_{4} \mathrm{Al}_{14} \mathrm{O}_{25}$ : Eu prepared in air atmosphere. Chem. Phys. Lett., 2003, 371(1): 1-6. 
[30] PENG MING-YING, PEI ZHI-WU, HONG GUANG-YAN, et al. The reduction of $\mathrm{Eu}^{3+}$ to $\mathrm{Eu}^{2+}$ in $\mathrm{BaMgSiO}_{4}$ : Eu prepared in air and the luminescence of $\mathrm{BaMgSiO}_{4}: \mathrm{Eu}^{2+}$ phosphor. J. Mater. Chem., 2003, 13(5): 1202-1205.

[31] ZENG Q, PEI Z, WANG S, et al. The reduction of $\mathrm{RE}^{3+}$ in $\mathrm{SrB}_{6} \mathrm{O}_{10}$ prepared in air and the luminescence of $\mathrm{SrB}_{6} \mathrm{O}_{10}: \mathrm{RE}^{2+}(\mathrm{RE}=\mathrm{Eu}$, Sm, Tm). Spectroscopy Letters, 1999, 32(6): 895-912.

[32] SALEM L. The sudden polarization effect and its possible role in vision. Acc. Chem. Res., 1979, 12(3): 87-92.

[33] PRITCHARD H, SKINNER H. The concept of electronegativity. Chem. Rev., 1955, 55(4): 745-786.

[34] CZAJA M, BODYŁ S, GŁUCHOWSKI P, et al. Luminescence properties of rare earth ions in fluorite, apatite and scheelite minerals. J. Aollys Compd., 2008, 451(1): 290-292.
[35] SABINA B. Luminescence properties of $\mathrm{Ce}^{3+}$ and $\mathrm{Eu}^{2+}$ in fluorites and apatites. Mineralogia, 2009, 40(1-4): 85-94.

[36] LI LI-YI, VIANA B, PAUPORTÉ T, et al. Deep Red Radioluminescence from a Divalent Bismuth Doped Strontium Pyrophosphate $\mathrm{Sr}_{2} \mathrm{P}_{2} \mathrm{O}_{7}$ : $\mathrm{Bi}^{2+}$.SPIE OPTO. International Society for Optics and Photonics, 2015: 936423.

[37] BLASSE G, MEIJERINK A, NOMES M, et al. Unusual bismuth luminescence in strontium tetraborate $\left(\mathrm{SrB}_{4} \mathrm{O}_{7}\right.$ : Bi). J. Phys. Chem. Solids, 1994, 55(2): 171-174.

[38] LI LI-YI, PENG MING-YING, VIANA B, et al. Unusual concentration induced antithermal quenching of the $\mathrm{Bi}^{2+}$ emission from $\mathrm{Sr}_{2} \mathrm{P}_{2} \mathrm{O}_{7}: \mathrm{Bi}^{2+}$. Inorg. Chem., 2015, 54(12): 6028-6034.

[39] GAFT M, REISFELD R, PANCZER G. Luminescence Spectroscopy of Minerals and Materials. Berlin Springer, 2005, 356.

\title{
F/CI 比对卤磷酸钙固溶体 $\mathrm{Bi}$ 离子掺杂位点及价态的调控
}

\author{
张庆福 ${ }^{1}$, 李 臣 $^{2}$, 宋志国 ${ }^{1}$, 李永进 ${ }^{2}$, 邱建备 ${ }^{1}$ ，杨正文 ${ }^{1}$ \\ (1. 昆明理工大学 材料科学与工程学院, 昆明 650093; 2. 云南工商学院, 昆明 651700)
}

摘 要: 本工作研究了卤素离子含量对卤磷酸䥻固溶体中 Bi 离子的价态和发光性能的影响。荧光分析表明, 卤素磷酸 钻中的 $\mathrm{Bi}^{2+} / \mathrm{Bi}^{3+}$ 可以通过其 $\mathrm{F}^{-} / \mathrm{Cl}^{-}$组分变化实现有效调控; 当卤素离子全部为 $\mathrm{Cl}^{-}$离子时, 晶体中 $\mathrm{Bi}^{2+}$ 全部消失。上述 现象的主要原因在于, 当卤素离子为 $\mathrm{F}$ 或者 $\mathrm{Cl}$ 时, 晶体中与其邻近的 $\mathrm{Ca}(2)$ 位点可以被分裂为 $\mathrm{Ca}(2) \mathrm{a}$ 或 $\mathrm{Ca}(2) \mathrm{b}$ 两种 不同的格位, 而 $\mathrm{Ca}(2) \mathrm{a}$ 位点则有利于实现 $\mathrm{Bi}^{3+}$ 的自还原。上述研究结果可以为 $\mathrm{Bi}$ 离子在晶体中的价态调控提供指导。 关 键 词: 卤磷酸钙; Bi; 发光性能; 调控 中图分类号: $\mathrm{O} 482$

文献标识码: A 